\title{
Microbial communities in an oligotrophic reservoir influenced by high levels of ionizing radiation
}

\author{
L.B. Ronqui ${ }^{1}$, H. Azevedo ${ }^{1}$, M.H.R. Seleghim ${ }^{2}$, C.R. Ferrari ${ }^{1}$, S. Rodgher ${ }^{2}$, \\ J.F. Macacini ${ }^{1}$, C.V. Roque ${ }^{1}$, G.B. Mourão ${ }^{3}$ and M.R.L. Nascimento ${ }^{1}$ \\ ${ }^{1}$ Poços de Caldas Laboratory, Brazilian Nuclear Energy Commission, Poços de \\ Caldas - Andradas Road, Km 13, 37701-970 Poços de Caldas, MG - Brazil \\ ${ }^{2}$ Department of Ecology and Evolutionary Biology, Federal University of São Carlos, \\ Washington Luis Road, (SP 310) Km 235, 13565-905 São Carlos, SP - Brazil \\ ${ }^{3}$ Department of Exact Sciences, "Luiz de Queiroz" College of Agriculture, São Paulo \\ University, Pádua Dias Avenue, 11, 13418-900 Piracicaba, SP - Brazil
}

\begin{abstract}
In this study, we investigated the microbial community (bacteria and protozooplankton) of a Brazilian reservoir that receives neutralized acid mine drainage flowing from piles of earth produced during uranium extraction. Thus, this research represents an attempt to fill a gap in the information on the ecology of freshwater microorganisms in tropical oligotrophic habitats, in particular in systems affected by high levels of the uranium. During the study, we observed very low chlorophyll $a$ contents and protozooplankton cell densities and biomass. These cell densities were between 0 and 89 cells $\mathrm{L}^{-1}$ and were lower than those frequently reported for oligotrophic freshwater lakes. In contrast, bacterial densities were normal or even slightly high, between 1.85 to $6.0 \times 10^{9}$ cells $\mathrm{L}^{-1}$. The present study has demonstrated very low protozooplankton cell densities and biomass in oligotrophic reservoir under the influence of acidic mining effluents and of high levels of ionizing radiation. It is likely that the ciliate cell densities and biomasses recorded in this study, which fall significantly below the previously published values, can be explained by the chronic fractionated exposure of these protozoa to the high levels of uranium to this system.
\end{abstract}

\section{INTRODUCTION}

Bacteria and protozoa are components of the microbial food web of the plankton and benthos in freshwater habitats. The bacteria are recognized as important decomposers and remineralizers of inorganic nutrients in aquatic ecosystems, as well as channeling carbon and energy, acquired from the dissolved organic matter excreted by algae, to organisms at higher trophic levels in the food chain [16, 17]. Few experimental or descriptive studies have been published on microbial food webs in oligotrophic and ultraoligotrophic temperate lakes, compared to their eutrophic and mesotrophic counterparts [18, 19]. According to Laybourn-Parry [19], the oligotrophic systems are harder to study, since they contain highly-stressed organisms at low densities. The Antas Reservoir (Minas Gerais state, Brazil), oligotrophic system, is located in a tropical region of raised background radioactivity (due to local uranium and thorium anomalies) and receives the neutralized acid leach solution draining from waste heaps generated by uranium mining. This study was a season-by-season analysis of the abundance and biomass of ciliated protozoa among the plankton of Antas Reservoir and their interactions with other components of the microbial food web (density and biomass of the dinoflagellate Peridinium sp., density of bacterial plankton and biomass of phytoplankton) and with the physical and chemical characteristics of the water. Thus, this research represents an attempt to fill a gap in the information on the ecology of freshwater 
microorganisms in tropical oligotrophic habitats, in particular in systems affected by high levels of the uranium.

\section{MATERIALS AND METHODS}

Antas Reservoir, is in the Brazilian state of Minas Gerais, at $1291 \mathrm{~m}$ above sea level, in a region that has dry, cool winters (May to August) and hot, wet summers (October to March). Samples were taken from the surface at three sites on the reservoir (A1, A2 and A3-S) and from the bottom at one of these sites (A3-B; depth $6.5 \mathrm{~m}$ ), at intervals of about 3 months: January, April, July and October 2006 and February 2007. Water was collected for all tests physical, chemical and biological (density and biomass of Protozoa ciliates and the dinoflagellate Peridinium sp. and bacteria density). Water transparency was measured with a Secchi disk. The $\mathrm{pH}$ values were measured using $\mathrm{pH}$ meter (model DM-21, Digimed) and electrical conductivity values were measured using electrical conductivity meter (model DM-31, Digimed) with selective electrode. Total suspended solids were analyzed by a method described by [14]. Water hardness $\left(\mathrm{Ca}^{2+}\right.$ and $\left.\mathrm{Mg}^{2+}\right)$, manganese and zinc were with a Liberty $\mathrm{RL}$ sequential ICP-OES (Liberty RL Varian, USA). Fluoride was estimated potentiometrically with an ionselective electrode [12]. Sulfate was analyzed by UV-Vis spectrophotometry, as described in ASTM [2]. To analyze uranium, was measured by absorbance at $650 \mathrm{~nm}$ in a UV-Vis spectrophotometer [7]. Thorium was determined by a method similar to that used for uranium, according Fukuma et al. [7]. The chemical data collected on the water sampled from the reservoir were compared with the limits adopted in the Brazilian guidelines (CONAMA Resolution 357) [4].

Ciliated protozoa and dinoflagellate Peridinium sp. were fixed water samples in the laboratory and specimens counted in Sedgwick-Rafter chambers under an optical microscope (Orthoplan, Ernest Leitz Wetzlar, Germany). The ciliated protozoa and the dinoflagellates were identified, counted and their densities recorded. In addition, linear measurements were made on about 20 specimens of each morphological type, in order to calculate the total biovolume of each type at each site and collection time, using the mathematical formulae most suited to the geometrical shape of the organism [14]. To estimate the biomass of the ciliates and dinoflagellate, the biovolumes were multiplied by the carbon conversion factors estimated by [13] and [3], respectively. The ciliated protozoa and dinoflagellates observed in the samples were grouped into nutritional types with a view to classifying them into trophic levels, as defined by [6] and [10], respectively. Aliquots of $1 \mathrm{~mL}$ of each fixed sample were stained with an aqueous solution of acridine orange [5]. After 5 minutes of staining, the sample was filtered on to a black polycarbonate membrane of pore size $0.22 \mu \mathrm{m}$ (Millipore) [8] and examined with a Zeiss-Axioplan 2 epifluorescence microscope (Zeiss, Germany). To calculate bacterial density, 300 microscope fields were counted on each membrane, at a magnification of $1000 \times$. Chlorophyll $a$ content in the $5 \mathrm{~L}$ water samples was determined as recommended by Marker et al. Its concentration in the extract was calculated from spectrophotometer readings by the equations provided by [11]. To estimate the biomass of the phytoplankton, the chlorophyll $a$ content $(\mathrm{w} / \mathrm{v})$ was multiplied by a carbon conversion factor of 67 [1]. An analysis of variance (ANOVA) was used to detect significant differences between water samples from different sites and collection times, in the results of the physical, chemical and biological analyses. The Principal Component Analysis (PCA) was applied in order to compare the distribution of environmental parameters, that is, physical and chemical variables as well as the biological variable chlorophyll $a$ on sites A1, A2, A3-S and A3-B, located in the Antas Reservoir. The Canonical Correlation Analysis (CCA) was applied in order verify the existence of a correlation between the environmental parameters and density and biomass of the microbial communities. In order to verify the significance level of environmental parameters as well as density and biomass, the Monte Carlo test was applied with 999 random permutations, with $p$ value lower or equal to 0,5 ( $p \leq 0,5)$. The Principal Component Analysis (PCA) as well as the Canonical Correlation Analysis (CCA) were performed with the aid of the software CANOCO 3.12 [9]. 


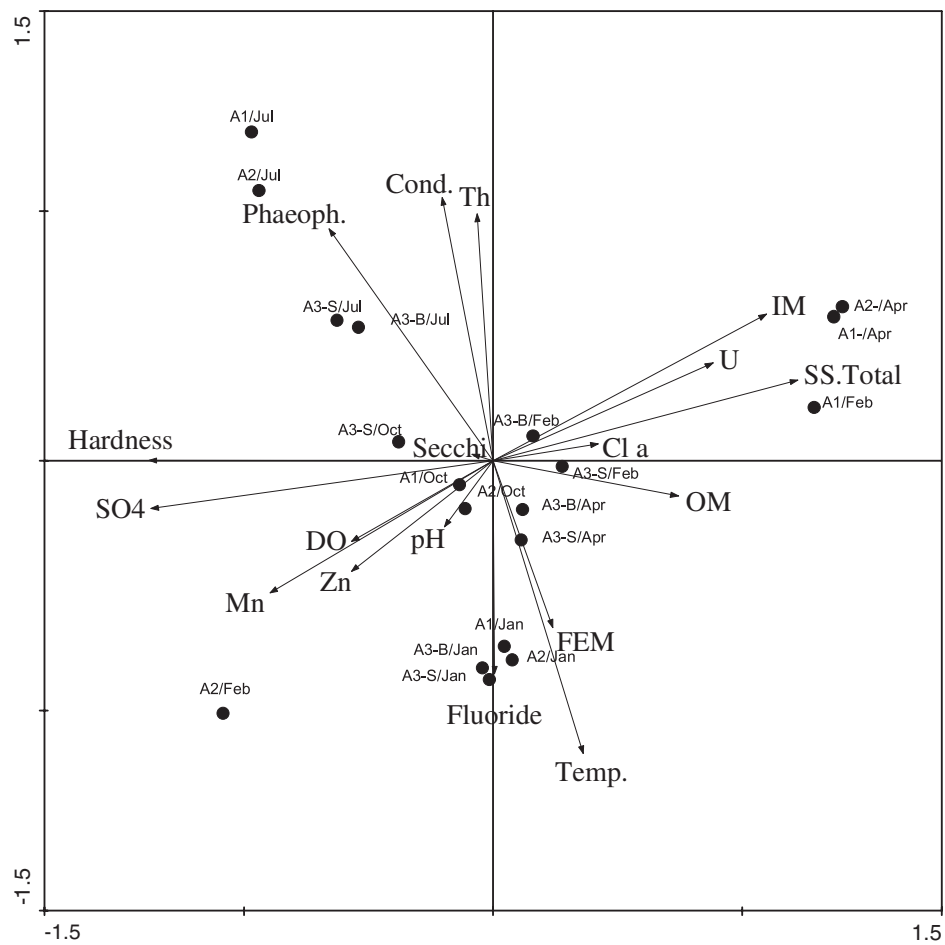

Figure 1. PCA ordination diagram of the A1, A2, A3-S and A3-B sites (Antas reservoir) in January, April, July and October 2006 and February 2007. SO4 = sulfate, Fluoride, Cond. = electrical conductivity, hardness = water hardness, $\mathrm{U}=$ uranium, $\mathrm{Th}=$ thorium, $\mathrm{DO}=$ dissolved oxygen, $\mathrm{Temp}=$ water temperature, $\mathrm{pH}=$ hydrogenionic potential, $\mathrm{Cla}=$ Chlorophyll a, Phaeophytin $=$ Phaeoph.., $\mathrm{IM}=$ inorganic matter, $\mathrm{OM}=$ organicmatter, SS. Total $=$ total suspended solids, Secchi $=$ water transparency, $\mathrm{FEM}=$ oxidation reduction potential, $\mathrm{Zn}=\mathrm{Zinc}$ and $\mathrm{Mn}=$ manganese.

\section{RESULTS}

Firstly, regarding the seasonal variations, it was noted that during the rainy season (February samples), the lowest mean values of $\mathrm{pH}$ and highest suspended solid contents were recorded. In fact, the February $\mathrm{pH}$ at all the sites, except A2, fell below the lower limit permitted by the regulatory body (CONAMA, 2005) in its Resolution 357. On the other hand, in the cool, dry season (July), the lowest mean suspended solid content and highest mean electrical conductivity were observed. The latter $\left(411 \mu \mathrm{S} . \mathrm{cm}^{-1}\right)$ was significantly higher $(P<0.05)$ than the conductivities measured in October $\left(192 \mu \mathrm{S} . \mathrm{cm}^{-1}\right)$ and January $\left(144 \mu \mathrm{S} \mathrm{cm}^{-1}\right)$. The water collected from site A2 was significantly harder $(P<0.05)$ than that from the site A1.

When the chemical variables under study (concentrations of $\mathrm{F}^{-}, \mathrm{SO}_{4}^{-2}, \mathrm{Mn}, \mathrm{Zn}$ and $\mathrm{U}$ ) were compared among collection sites, A2 stood out in terms of the number of maximum values observed there. Fluoride levels exceeded the limits set by Conama in Resolution 357 (CONAMA, 2005) in all samples except those from A1 and A2 in April and from A1 in February, and sulfate concentrations were also found to be above the Conama limit $\left(250 \mathrm{mg} \mathrm{L}^{-1}\right)$ at site A2, in July $\left(278.7 \mathrm{mg} \mathrm{L}^{-1}\right)$ and February $\left(412.3 \mathrm{mg} \mathrm{L}^{-1}\right)$. All the manganese concentrations sufficiently high to be detected by the method used in this study were, in fact, above the Conama limit $\left(0.1 \mathrm{mg} \mathrm{L}^{-1}\right)$ for this metal (CONAMA, 2005). Among these measurable values, the mean concentration at $\mathrm{A} 2\left(5.13 \mathrm{mg} \mathrm{L}^{-1}\right)$ was significantly 


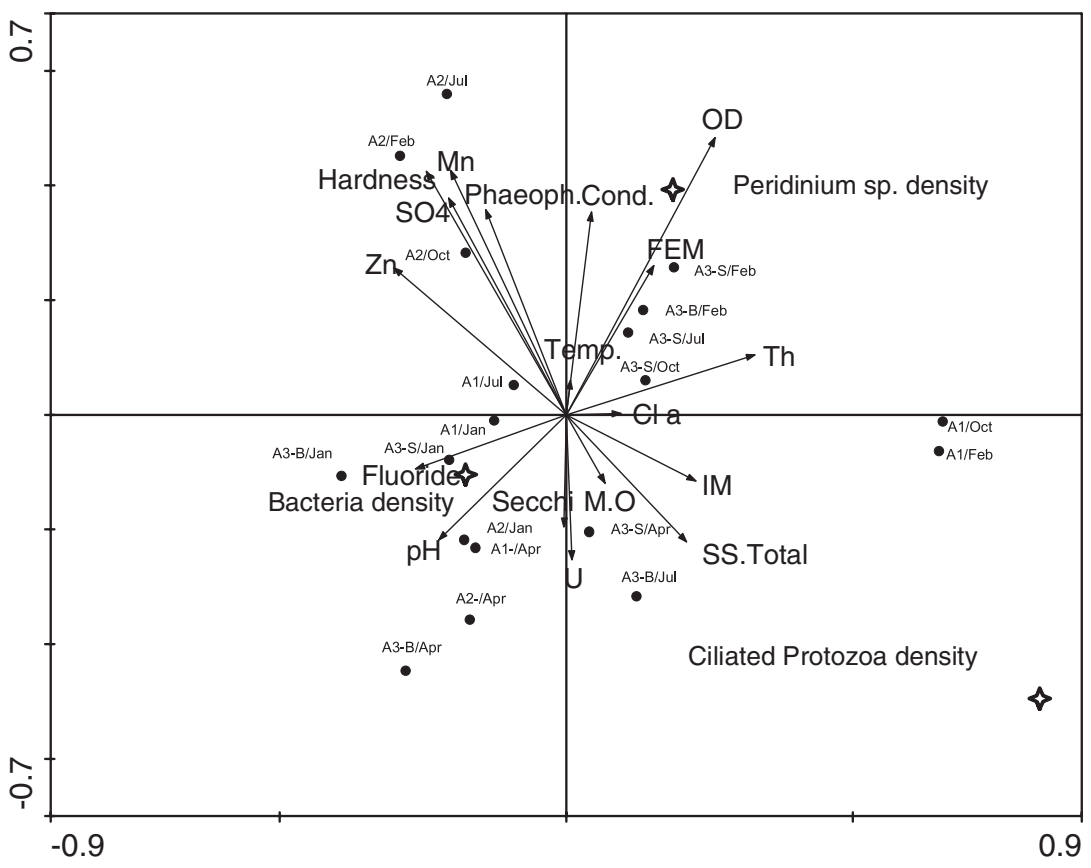

Figure 2. CCA ordination diagram of the Ciliated Protozoa density, Bacteria density and the dinoflagellate Peridinium sp. density at the A1, A2, A3-S and A3-B sites (Antas reservoir) in January, April, July and October 2006 and February 2007. SO4 = sulfate, Fluoride, Cond. = electrical conductivity, hardness = water hardness, $\mathrm{U}=$ uranium, $\mathrm{Th}=$ thorium, $\mathrm{DO}=$ dissolved oxygen, $\mathrm{Temp} .=$ water temperature, $\mathrm{pH}=$ hydrogenionic potential, $\mathrm{Cla}=$ Chlorophyll a, Phaeoph $=$ Phaeophytin, $\mathrm{IM}=$ inorganic matter, $\mathrm{OM}=$ organic matter, SS.Total $=$ total suspended solids, $\mathrm{Secchi}=$ water transparency, $\mathrm{FEM}=$ oxidation reduction potential, $\mathrm{Zn}=$ Zinc and $\mathrm{Mn}=$ manganese.

higher $(P<0.05)$ than those at A3-S $\left(1.70 \mathrm{mg} \mathrm{L}^{-1}\right)$ and A1 $\left(0.76 \mathrm{mg} \mathrm{L}^{-1}\right)$. Zinc levels in the water taken from site A2, in February $\left(2.03 \mathrm{mg} \mathrm{L}^{-1}\right)$ and July $\left(0.21 \mathrm{mg} \mathrm{L}^{-1}\right)$, were also above the limit $\left(0.18 \mathrm{mg} \mathrm{L}^{-1}\right)$ stipulated in Resolution 357 (CONAMA, 2005). Finally, the uranium concentrations recorded in April, at A1 and A2 $\left(0.11 \mathrm{mg} \mathrm{L}^{-1}\right)$, and in October, at A1 $\left(0.08 \mathrm{mg} \mathrm{L}^{-1}\right), \mathrm{A} 2$ and A3-S $\left(0.06 \mathrm{mg} \mathrm{L}^{-1}\right)$, were above the reference limit published in the Brazilian law based on Resolution 357 $\left(0.02 \mathrm{mg} \mathrm{L}^{-1}\right)$ (figure 1). No limits are as yet defined in Brazilian Law for thorium concentration in freshwater, but the highest levels were detected in January at A1 $\left(0.03 \mathrm{mg} \mathrm{L}^{-1}\right)$ and in July at A3-F (0.06 $\left.\mathrm{mg} \mathrm{L}^{-1}\right)$.

The plankton bacteria counted in the water samples from Antas Reservoir exhibited the following mean densities (in units of $10^{9}$ ind $\mathrm{L}^{-1}$ ): 2.90 in January, 6.00 in April, 6.00 in July, 5.74 in October and 1.85 in February. Regarding the densities of ciliates and dinoflagellates, the mean value for ciliated protozoa varied from 7.5 ind $\mathrm{L}^{-1}$ in January to $37.3 \mathrm{ind} \mathrm{L}^{-1}$ in October, while the number of Peridinium dinoflagellates ranged from 2,437 ind $\mathrm{L}^{-1}$ in April to 44,197 ind $\mathrm{L}^{-1}$ in October. The average biomasses observed ranged from $0.01 \mu \mathrm{g} \mathrm{C} \mathrm{L}^{-1}$ (April) to $0.05 \mu \mathrm{g} \mathrm{C} \mathrm{L}^{-1}$ (October) for the ciliates and from $0.18 \mu \mathrm{g}$ $\mathrm{C} \mathrm{L}^{-1}$ (April) to $3.26 \mu \mathrm{g} \mathrm{C} \mathrm{L}{ }^{-1}$ (February) for the dinoflagellates.

Turning now to the distribution of these microorganisms along the reservoir, the highest ciliate densities were found in two of the five field collections, in water collected from the head of the reservoir (A1) in October $\left(87.0\right.$ ind $\left.\mathrm{L}^{-1}\right)$ and February $\left(89\right.$ ind $\left.\mathrm{L}^{-1}\right)$, while the lowest were recorded in three collections, in water from A2 (near the mine affluent) in July $\left(3.0\right.$ ind L $\left.^{-1}\right)$, October $\left(6.0 \mathrm{ind} \mathrm{L}^{-1}\right)$ and February $\left(3.0\right.$ ind $\left.\mathrm{L}^{-1}\right)$. On the other hand, the highest densities of plankton bacteria were seen in water 


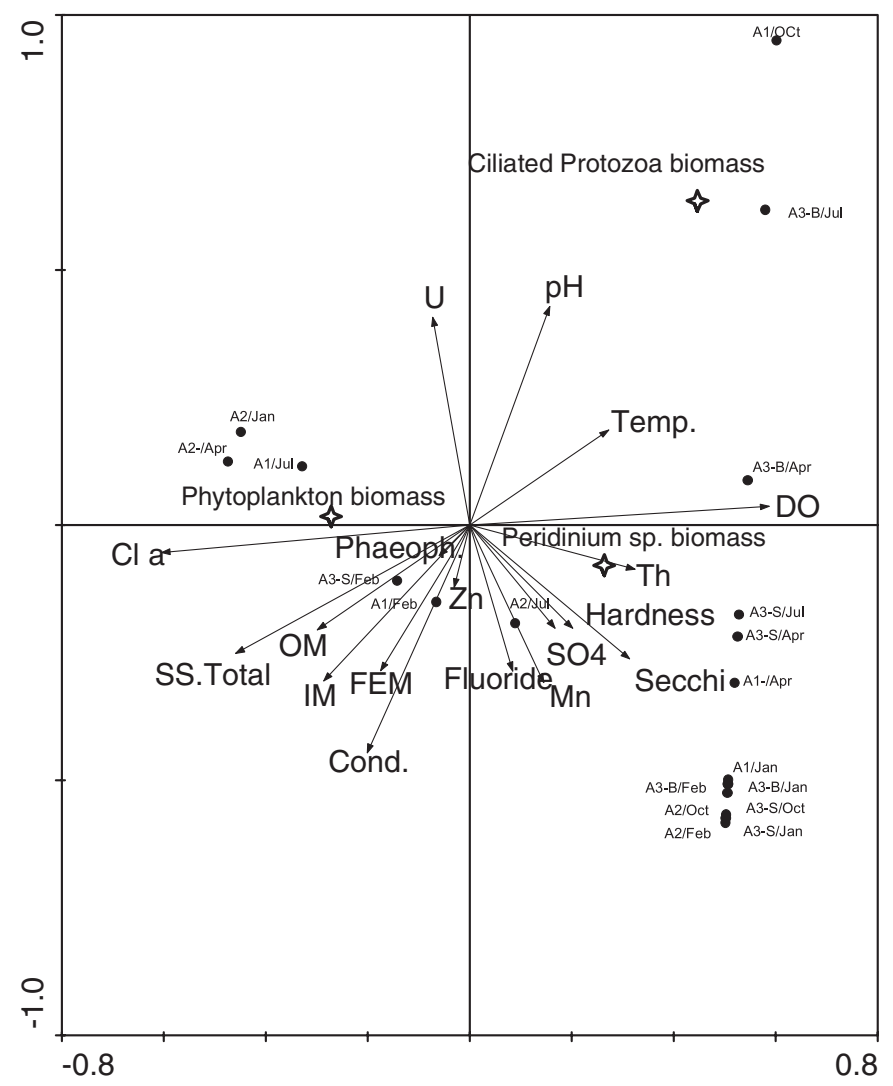

Figure 3. CCA ordination diagram of the ciliated protozoa biomass, phytoplankton biomass and the dinoflagellate Peridinium sp. biomass at the A1, A2, A3-S and A3-B sites (Antas reservoir) in January, April, July and October 2006 and February 2007. SO4 = sulfate, Fluoride, Cond. = electrical conductivity, hardness = water hardness, $\mathrm{U}=$ uranium, $\mathrm{Th}=$ thorium, $\mathrm{DO}=$ dissolved oxygen, $\mathrm{Temp}=$ water temperature, $\mathrm{pH}=$ hydrogenionic potential, $\mathrm{Cla}=$ Chlorophyll a, Phaeophytin $=$ Phaeoph., $\mathrm{IM}=$ inorganic matter, $\mathrm{OM}=$ organic matter, $\mathrm{SS}$.Total $=$ total suspended solids, Secchi $=$ water transparency, $\mathrm{FEM}=$ oxidation reduction potential, $\mathrm{Zn}=$ Zinc and $\mathrm{Mn}=$ manganese.

taken from A2 in April $\left(8 \times 10^{9}\right.$ ind $\left.\mathrm{L}^{-1}\right)$ and October $\left(9 \times 10^{9}\right.$ ind $\left.\mathrm{L}^{-1}\right)$, while the lowest were recorded at A3-S and A3-F $\left(1.1 \times 10^{9}\right.$ ind $\left.\mathrm{L}^{-1}\right)$, in February. Finally, the highest densities of Peridinium sp. were found in water from $\mathrm{A} 1$ in October $\left(79,380\right.$ ind $\left.\mathrm{L}^{-1}\right)$ and February $\left(58,510\right.$ ind $\left.\mathrm{L}^{-1}\right)$, while the lowest was observed in the sample taken from site A3-F in April (690 ind $\mathrm{L}^{-1}$ ) (figure 2).

The two highest biomasses of ciliated protozoa were recorded in water samples taken from the head of the reservoir (A1) in October $\left(1.21 \mu \mathrm{g} \mathrm{C} \mathrm{L}^{-1}\right)$ and from site A3-S in July $\left(0.075 \mu \mathrm{g} \mathrm{C} \mathrm{L} \mathrm{L}^{-1}\right)$, while the lowest ciliate biomasses were found in water collected in January, from the sites A3-F $\left(0.001 \mu \mathrm{g} \mathrm{C} \mathrm{L}^{-1}\right)$ and A3-S $\left(0.003 \mu \mathrm{g} \mathrm{C} \mathrm{L}^{-1}\right)$. The two largest Peridinium sp. biomasses were observed in water from A3$\mathrm{S}$ in February $\left(6.53 \mu \mathrm{g} \mathrm{C} \mathrm{L}^{-1}\right)$ and from A1 in October $\left(6.08 \mu \mathrm{g} \mathrm{C} \mathrm{L}^{-1}\right)$ and two smallest masses for this dinoflagellate occurred in the water collected in April, at A3-F $\left(0.04 \mu \mathrm{g} \mathrm{C} \mathrm{L}^{-1}\right)$ and A2 $\left(0.10 \mu \mathrm{g} \mathrm{C} \mathrm{L}^{-1}\right)$. The mean phytoplankton biomass (over time) at the site $\mathrm{A} 2$ was significantly greater $(P<0.05)$ than in samples collected at the other sites. The two largest phytoplankton biomass values were recorded in water from site A3-S in February $\left(33.66 \mu \mathrm{g} \mathrm{C} \mathrm{L}^{-1}\right)$ and from A2 in January $\left(20.03 \mu \mathrm{g} \mathrm{C} \mathrm{L}^{-1}\right)$ (figure 3). 


\section{CONCLUSIONS}

The present study has demonstrated very low protozooplankton cell densities and biomass in oligotrophic reservoir under the influence of acidic mining effluents and of high levels of ionizing radiation. It is likely that the ciliate cell densities and biomasses recorded in this study, which fall significantly below the previously published values, can be explained by the chronic fractionated exposure of these protozoa to the high levels of uranium to this system.

In addition, the microbial communities in the Antas Reservoir were influenced by another chemical stress effect related to the release of treated radioactive effluents from the uranium mine. Among the studied groups (ciliated protozoa biomass and density, bacterioplankton density, Peridinium sp biomass and density), the protozooplankton was the most sensitive to the synergistic effect due to fractionated chronic exposition to uranium and the release of radioactive effluents treated by uranium milling.

\section{Acknowledgments}

We thank the Minas Gerais Research Foundation (FAPEMIG), the Brazilian Scientific and Technological Development Council (CNPq) for the financial support and also A. L. Bruschi for the technical support during this study.

\section{References}

[1] American Public Health Association (1995) Standard Methods for the Examination of Water and Waste Water, 2nd edn. APHA, Washington, U.S.A., 1268 pp.

[2] American Society for Testing and Materials (1980). Analytical Methods (Spectroscopy; Chromatography; Computerized Systems). ASTM, Annual Book of ASTM Standards. Part 42, p. 646. Philadelphia.

[3] Borsheim K.Y. \& Bratbak G. (1987) Cell volume to cell carbon conversion factors for a bacterivorous Monas sp. enriched from seawater. Marine Ecology, 36, 171-175.

[4] Conselho Nacional do Meio Ambiente CONAMA Resolution 357 (2005) 17 de março de 2005. Resolução do CONAMA para a classificação de águas de acordo com sua composição e os teores máximos de substâncias potencialmente prejudiciais. 23p.

[5] Daley R.J. \& Hobbie J.E. (1975) Direct counts of aquatic bacteria by a modified epifluorescence technique. Limnology and Oceanography, 20, 875-882.

[6] Foissner W.J. \& Berger H. (1996) A user friendly guide to the ciliates (Protozoa, Ciliophora) commonly used by hydrobiologists as bioindicators in rivers, lakes, and waste waters, with notes on their ecology. Freshwater Biology, 35, 375-482.

[7] Fukuma H.T., Fernandes E.A.N., Nascimento M.R.L. \& Quinelato A.L. (2001) Separation and spectrophotometric determination of thorium contained in uranium concentrates. Journal of Radioanalytical and Nuclear Chemistry, 248, 549-553.

[8] Hobbie J.E., Daley R.J. \& Jasper S. (1977) Use of nuclepore filters for counting bacteria by fluorescence microscopy. Applied and Environmental Microbiology, 33, 1225-1228.

[9] Těr Braak, C.J.F., Šmilauer, P. (2002). Canoco reference manual and CanoDraw for Windows user's guide: software for canonical community ordination. New York: Ithaca Microcomputer Power.

[10] Laybourn-Parry J. (1992) Protozoan Plankton Ecology. Chapman \& Hall, London.

[11] Lorenzen C.J. (1967) Determination of chlorophyll and phaeopigments: spectrophotometric equations. Limnology and Oceanography, 12, 343-346.

[12] Nascimento M.R.L., Fukuma H.T. \& Hortellani M.A. (1988) Projeto Itataia - Controle de processo na produção de ácidos fosfórico e urânio. Poços de Caldas: INB p. 143. (Manual de Métodos e Análises Químicas). 
[13] Putt M. \& Stoecker D.K. (1989) An experimentally determined carbon: volume ratio for marine "oligotrichous" ciliates from estuarine and coastal waters. Limnology and Oceanography, 34, 1097-1103.

[14] Sun J. \& Liu D. (2003) Geometric models for calculating cell biovolume and surface area for phytoplankton. Journal of Plankton Research, 25, 1331-1346.

[15] Teixeira C., Tundisi J.G. \& Kutner M.B. (1965) Plankton studies in a mangrove II. The standing stock and some ecological factors. Boletim do Instituto Oceanográfico, 24, 23-41.

[16] Pomeroy L. R. (1974) The oceans food web, a changing paradigm. BioScience, 24, 499-504.

[17] Azam F., Fenchel T., Field J.G., Gray J.S., Meyer-Reil L.A. \& Thingstad F. (1983) The ecological role of water-column microbes in the sea. Microbial Ecology Progress Series, 10, 257-263.

[18] Burns C.W. \& Schallenberg M. (1998) Impacts of nutrients and zooplankton on the microbial food web of an ultra-oligotrophic lake. Journal of Plankton Research, 20, 1501-1525.

[19] Laybourn-Parry J. (1998) Seasonal heterotrophic flagellate and bacterial plankton dynamics in a large oligotrophic lake - Loch Ness, Scotland. Freshwater Biology, 39, 1-8. 